\title{
Teaching Material Development of Macromedia Flash 8.0-Based Production Écrite Pre Avancée
}

\author{
Tengku Ratna Soraya ${ }^{1}$, Nurilam Harianja ${ }^{2}$, Hesti Fibriasari ${ }^{3}$ \\ 1,2,3 Universitas Negeri Medan, Medan, Indonesia \\ trs_luthfi@yahoo.fr
}

\section{Abstract}

Production Écrite Pre Avancée course is a course that aims to develop skills in working together and collaborating, adapting, being responsible, analyzing information and data, thinking critically and solving problems, creativity, communicating through writing, and using information and communication technology in learning activities on French writing at advanced level to achieve the students' ability on writing complex French sentences that refer to the European standard curriculum (Cadre Européen Commun de Référence Pour Les Langues (CECRL) on Niveau B1 DELF. Teaching material development of Macromedia Flash 8.0based Production Écrite Pre Avancée has a purpose for students to improve the writing ability on French text B1 level. This research makes teaching materials by using macromedia flash 8.0 software in Production Écrite Pre Avancée course. The research method used is Research and Development. The research is held at the French Language Study Program at FBS UNIMED by developing lecture teaching materials, to find out that these teaching materials can improve writing skills by French students Unimed.

Keywords

teaching material

development; production

écrite pre avancée;

macromedia flash 8.0

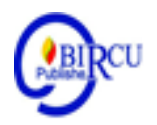

\section{Introduction}

Writing skill is one of the important skills that must be mastered by students, because they must master grammar to write French correctly. Writing is a linguistic skill that must be learned continuously, good writing is writing that provides clear information for the reader. In French learning, writing competence is one of the big points given in lectures. Writing becomes a benchmark in expressing one's opinion in writing, besides writing becomes an important point in the selection to apply for job in French companies. Therefore, material of writing learning must be adjusted to the needs of students in the workforce later. Learning materials will be arranged into writing teaching materials.

Teaching material is information, tool, and text that teachers need to plan and to study about learning implementation. Teaching materials are all forms of materials which are used to help the teachers / instructors for doing teaching and learning activities in class. The material can be either written or unwritten material. Teaching material is a set of materials that is arranged systematically both written and unwritten, so as to create an environment / atmosphere that allows students to learn. Writing teaching material has been developed which was made by the France with a platform provided free of charge by the French government such as TV5Monde, RFI, Bonjour de France and many others. The platform requires lecturers and students to be more creative to realize the educational industry revolution 4.0. The industrial revolution 4.0 has the first characteristic which is lecturer as a team leader who collaborates with students to create science and technology supported by various learning resources from the internet. The second one, learning materials are suitable to practical needs which are sourced from the internet. Third, the opened learning process is to enhance learner's creativity, to build social networks across classrooms and scientific disciplines, 
adaptive learning that is controlled by many Artificial Intelligence Portals (internet-based). Fourth, learning is no longer depends on physical buildings because learning activities are carried out openly with lecturers exchange across regions in national scope such as offering degrees and double degrees, and accreditation from many internationally recognized institutions. Fifth, students have the autonomy to prepare learning plans that are assisted by lecturers as advisors and supported by Artificial Intelligence Portals, where these learning plans can be updated continuously through adaptive mechanisms. Sixth, the E-learning management system is conducted in an integrated manner with many Artificial Intelligence applications.

The use of IT in the world of education is very broad, teaching and learning process becomes more creative and does not use the same teaching materials. The use of IT makes teaching materials more varied and developing in accordance with the times. Foreign language learning is currently created with infinite reach so that the learning process is not always in the classroom but it can be done anywhere and anytime. This situation is used by teachers by creating creative ideas to create learning materials by utilizing IT which can add the treasury of foreign language learning. French language teachers strive to make IT-based teaching materials as an effort to improve the ability of French learners in reading, writing, speaking and listening competencies.

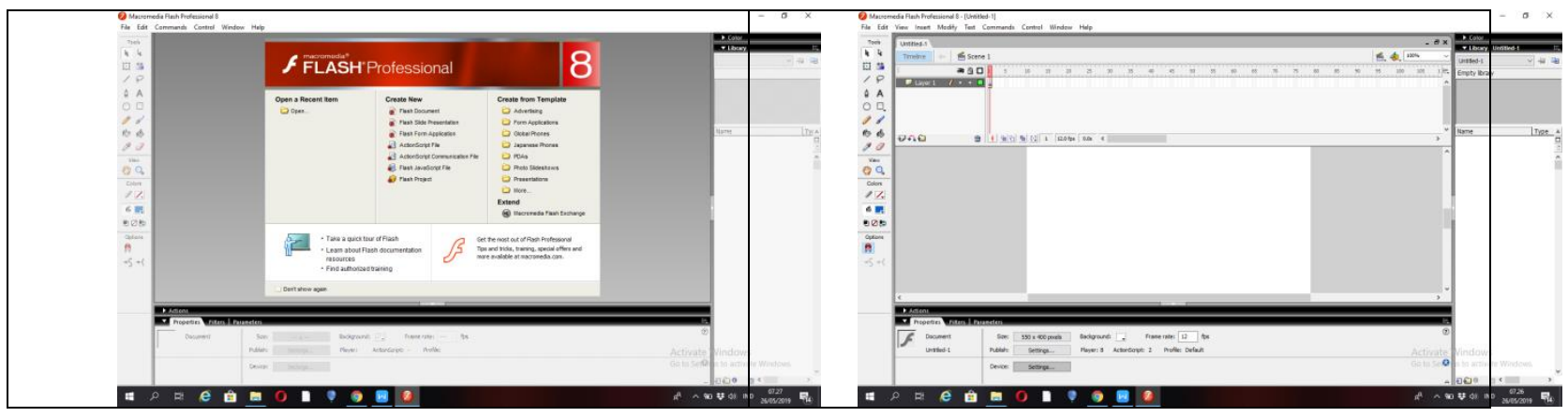

Figure 1. Display of Macromedia Flash 8.0

Figure 1 Menubar: contains general commands that are often used to operate. Toolbox: contains the main tool for drawing consisting of four parts namely Tools, View, Colors, and Options. Tools consist of Selection Tool that is useful for selecting objects, Subselection Tool that is useful for selecting parts of objects, Free Transform tool that is useful for resizing, rotating objects, line tool is for drawing lines, lasso tool is for selecting objects freely, pen tool is for drawing objects freely with pen, text tool is for writing text, oval tool is for drawing oval objects, rectangle tool is for drawing square objects, pencil tool is for making curves, brush tool is for drawing trace-shaped objects, ink bottle tool is for filling color of line objects, paint bucket tool is for filling the color of object's fill and eraser tool is for erasing the object. View consists of hand tool which is to move the stage; zoom tool is to zoom in and out on the stage display. Colors consist of stroke color which is to fill the color on a line; fill color is to fill a color on an object's fill. Options consist of the choices of the currently selected tool. Stage: is a workplace. The result of stage is the display of results when the flash program runs. Timeline: contains the stored stage display in frames. Timeline is useful for setting the time display per frame. By default, frames will run at 12 frames per second (12 fps). Timeline provides layers that are transparent layers from the frame. Layers are useful for making animation easier. Library: contains a collection of image objects that 
already exist or are stored in flash program. Library can be likened to a library. Properties: contains information and parts that can be treated to the selected object. Colors contains about adjusting colors, color transparency. Color is above the library.

Macromedia Flash is a platform of multimedia and software which is used for animation, games and internet enrichment applications that can be seen, played and run on Adobe Flash Player. Flash is often used to add streaming video or audio player, advertisement, and interactive multimedia content for web pages (Wales \& Sanger, 2013a, p. 1). Production Écrite Pre Avancée teaching material was developed based on Macromedia Flash 8.0 which aims to improve the ability to write French texts of students that contains sound and graphical design, which are expected to arise learning interest and to increase understanding of learning materials for Production Écrite Pre Avancée, teaching materials based on macromedia flash 8.0 contain introduction, which includes the instructions for using the program, a brief description of the material, examples of practice questions.

Based on the description above, the problems that can be formulated in this study are: (1) How is the teaching materials development of macromedia flash 8.0-based Production Écrite Pre Avancée?, (2) How is the feasibility of teaching materials Macromedia flash 8.0based Production Écrite Pre Avancée?, 3) How is the effectiveness of teaching materials Macromedia Flash 8.0-based Production Écrite Pre Avancée in improving writing competency in French Study Program Unimed?

Based on the formulation of the problems, the objectives of this study are to: (1) Describe the development of Production Écrite Pre Avancée teaching materials based on macromedia flash 8.0, (2) Describe the feasibility of Production Écrite Pre Avancée teaching materials based on Macromedia flash 8.0, (3) Analyze the effectiveness of Production Écrite Pre Avancée teaching materials based on macromedia flash 8.0 in improving writing competence in the French Study Program Unimed.

\section{Review of Literature}

\subsection{Development of Teaching Materials}

According to Majid (2008) Communicative language teaching materials should be supplemented with learning instructions (student / teacher instructions), competencies to be achieved, supporting information, exercises, work instructions, can be in the form of worksheets and evaluations. Theoretically, teaching materials include a collection of information, tools, texts, or any form of material that is arranged systematically, whether written or not, and is required by the teacher for planning and studying the implementation of learning so as to create an environment / atmosphere that allows students to learn. Thus in general, the existence of teaching materials in the form of materials as stated above can provide ease for teachers in planning, implementing, and evaluating teaching and learning activities.

\subsection{Macromedia Flash $\mathbf{8 . 0}$}

Macromedia Flash is program for creating animations and professional web applications. Macromedia Flash is widely used to create games, cartoon animations, and interactive multimedia applications such as product demos and interactive tutorials. Macromedia's software output is program for designing animated graphics that are very popular and widely used by graphic designers. The advantage of flash lies in its ability to produce animated motion and sound. The early development of flash was widely used for 
animation on websites, but nowadays it is starting to be widely used for learning media because of its advantages. Macromedia Flash is combination of learning concepts with audiovisual technology that is able to produce new features that can be utilized in education. Multimedia-based learning can certainly provide more interesting learning materials, not monotonous, and facilitate material delivery. Students can learn certain learning material independently with a computer equipped with multimedia programs. Macromedia Flash has a number of advantages including: consistent, flexible animations and images for any window size and screen resolution on the user's monitor, image quality is maintained, the loading time of the program is relatively fast, the program produced is interactive, easy to create animations, can be integrated with several other programs, can be used to make short films or cartoons, presentations, and others.

\subsection{Writing}

French learning has four competencies, one of which is writing competence. In this modern life, writing is very necessary especially for people who are educated, because writing is used for reporting / approving, influencing, serving purposes as can be achieved well by people who can structure their thoughts and express clearly, this clarity is according to thought, organization, use of words, and sentence structure. According to Tarigan (2013), writing is downing or depicting graphical symbols that describe a language which is understood by someone, so that other people can read the symbols of the graph if they understand the language and graphical images. Pictures or paintings may also convey meaning, but they are not able to describe language units. Writing is a representation of a part of the unity of language expression. Writing is one of the most important language skills to be master. Thus, writing skill becomes language skill that needs serious attention.

\subsection{Production Écrite Pre Avancée}

The Production Écrite Pre Avancée course is an advanced writing course given to students in the $5^{\text {th }}$ semester which aims to develop skills of working together and collaborating, adapting, taking responsibility, analyzing information and data, thinking critically and solving problems, creativity, communicating through writing, and using information and communication technology in learning activities of advanced French writing to achieve the ability of students to write complex French sentences that refer to the European standard curriculum (Cadre Européen Commun de Référence Pour Les Langues (CECRL) on Niveau B1 DELF.

\subsection{French Learning}

Teaching and learning are two-way communication between teachers and learners by using learning tools. Learning tools in the form of teaching materials, media, models, and methods become facilitators to convey messages or learning materials. Learning material which is delivered to learners is strongly influenced by the ability of learners with the existence of learning resources that can make learners be able to learn independently suit to visual, auditor and kinesthetic abilities possessed by the learner. According to Nursalam (2008) in Suryaman, that determining of the right method selection should consider the right aspects which is; consider the aspects to be achieved, which refers to the outline of learning programs that are divided into two types: 
1) The learning process is able to encourage learners to organize and to fill new experiences based on past experiences. Example: question and answer exercises, interviews, consultations, sensitivity exercises, etc.

2) The learning process is designed to increase the transfer of new knowledge, new experiences, and new skills so that they can encourage each of them to achieve as much as possible the knowledge they want, what they need, and the skills needed. Example: learning to operate computer.

The use of learning media based on Macromedia Flash 8.0 greatly helps learners to learn foreign languages by online.

\section{Research Method}

This research used R\&D approach (Research and Development). R\&D research is a basic research activity to get information on user needs (needs assessment), then continued development activities to produce products and test the effectiveness of the products. In this research used the $R \& D$ approach because in this research will produce products in the form of interactive learning media Production Écrite Pre Avancée course. Borg and Gall revealed there are 10 steps in the development research process, but in Puslitjaknov Team (2008: 11), development research procedures according to Borg and Gall can be done more simply involving 5 main steps, namely: (1) Conducting an analysis of products to be developed; (2) Developing initial products; (3) Expert validation and revision; (4) Small-scale field trials and product revisions; (5) Large-scale field trials and final products. The steps in the development procedure can be described as follows:

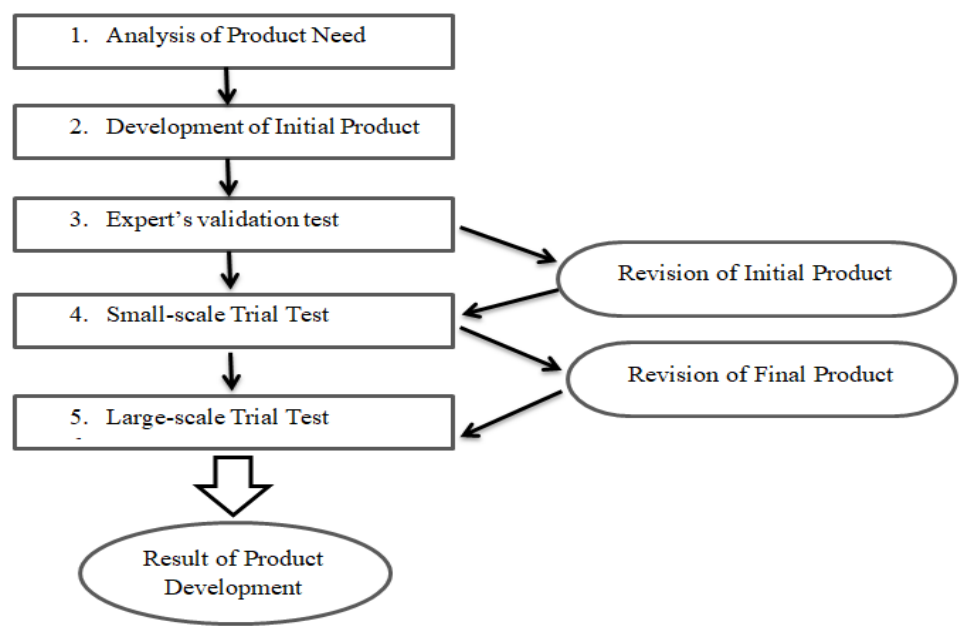

Figure 2. Procedure of Research Development

Data collection techniques which were used in this study were observation, interviews, and questionnaires. Observations were conducted when the research will be done to obtain data as a basis for conducting research and development. Interviews were conducted with lecturers in Production Écrite Pre Avancée course and students to obtain data on needs in research and development. The questionnaire is used to obtain quality assessment data for feasibility of developed media according to media experts, and also questionnaires are to obtain quality assessment data from material experts, as well as students on small-scale field trials. 


\subsection{Need Analysis}

\section{Discussion}

Data of need analysis were obtained through questionnaires given. Based on the answers given, it can be concluded that the development of Production Écrite Pre Avancée teaching materials is necessary.

\subsection{Description of Initial Product}

The results of producing this initial product were research instruments in the form of lattice and questionnaires for analyzing needs for students, syllabus, lesson plans, and worksheets, lattice and questionnaire sheets for experts, users, and students.

Products of learning media are made by using Macromedia Flash program. In addition, these products also use two

\subsection{Product Testing and Revision}

At this stage, researchers used the Likert scale to determine the validation assessments of data from language learning experts, media experts, and students. The validation from language learning experts on the initial product showed that the developed learning media are classified as good. Furthermore, in the validation stage the experts of language learning in the post-revision stage showed that the media produced was very feasible to be tested in the field. The experts also said that the media that had been designed was feasible to use.

\section{Conclusion}

Based on the results of research and product development conducted by researchers, it can be concluded as follows:

1) Based on the needs analysis through questionnaires for students and interviews with lecturers of Production Ecrite Pre Avancée course, it can be seen that the teaching material for Production Ecrite Pre Avancée using Macromedia Flash 8 is needed to improve the writing skill of fifth semester French students.

2) The results of these research and development are the teaching materials for Production Ecrite Pre Avancée using Macromedia Flash 8 to improve the writing skill of the fifth semester French students.

3) The use of Macromedia Flash 8 in Production Ecrite Pre Avancée teaching material has a good impact in improving the writing skill of fifth semester French students.

Based on the above conclusions, the authors propose several suggestions, namely:

1) For lecturers, this teaching material can be used as writing learning material for fifth semester students

2) For students, this teaching material can be used to practice writing French text.

3) For researchers, this product is a new teaching material that requires further research to determine the effectiveness of using Macromedia Flash 8 to improve writing skill.

\section{References}

Arsyad, Azhar . 2009. Media Pembelajaran . Jakarta : Rajawali pers

Dick, W., Carey, L., \& Carey, J. O. (2001). The systematic design of instruction (5th ed.). New York: Addison-Wesley Educational Publisher Inc.

Ifeoma, M. M. (2013). Use of instructional materials and education performance of student in integrated science (a case study of Unity Schools in Jalingo, Taraba 
state, Nigeria). IOSR Journal of Research \& Method in Education (IOSRJRME), 3(4), 07-11.

Majid, A. (2009). Perencanaan pembelajaran mengembangkan kompetensi guru. Bandung: PT Remaja Rosdakarya.

Purwanto, P.P. (2001). Penulisan bahan ajar. Jakarta: PAU-PPAI, Universitas Terbuka.

Unité des Politiques linguistiques, Cadre européen commun de référence. Strasbourg www.coe.int/lang-CECR

Widodo, C.S. \& Jasmadi. (2008). Panduan menyusun bahan ajar berbasis kompetensi. Jakarta: $\quad$ PT Elex Media Komputindo. 